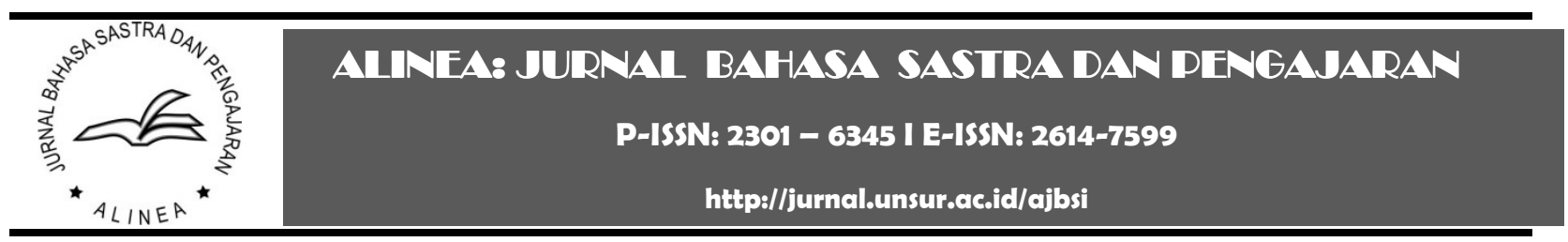

\title{
EFEKTIVITAS MODEL PEMBELAJARAN BERBASIS PROYEK DALAM PJJ TERHADAP PEMAHAMAN MATERI
}

\author{
Atika Rizki Khoirun Nisa \& Aninditya Sri Nugraheni \\ Universitas Islam Negeri Sunan Kalijaga Yogyakarta, Indonesia
}

Riwayat artikel:

Dikirim: 12 Januari 2021

Direvisi: 31 Maret 2021

Diterima: 3 April 2021

Diterbitkan: 27 April 2021

Katakunci:

PJJ, Project Based Learning, materi

Keywords:

PJJ, Project Based Learning, material

Alamat surat

atikarkn@gmail.com

\begin{abstract}
Abstrak:
Artikel ini membahas efektivitas model pembelajaran Project Based Learning (PBL) dalam PJJ terhadap pemahaman materi. Metode penelitian yang digunakan pada yaitu kuantitatif dengan menggunakan angket kuesioner dan skala likert. Subjek penelitian yaitu siswa di berbagai daerah sebanyak 50 responden. Hasil penelitian menunjukkan bahwa 15 responden berada pada interval penilaian 79,9-95 (sangat efektif), 29 responden pada interval penilaian 64,7-79,8 (efektif), dan 6 responden pada interval penilaian 49,564,6 (cukup efektif). Berdasarkan hasil yang diperoleh Project Based Learning efektif digunakan yaitu berada pada interval penilaian 64,7-95. Dengan demikiaan, dapat dikatakan efektivitas model pembelajaran PBL (Project Based Learning) dalam PJJ erhadap pemahaman materi siswa ini masuk dalam kategori efektif.
\end{abstract}

\section{Abstract:}

This article discusses the effectiveness of the PBL (Project Based Learning) learning model in distance learning on students' understanding of the material. The research method used in this research was quantitative by using questionnaire and likert scale. The research subjects were 50 students in various regions. The result of research shows that 15 respondents were at the interval 79,9-95 (very effective), 29 respondents were at the interval 64,7-79,8 (effective), and 6 respondents were at the interval 49,5-64,6 (moderately effective). It shows that Project-Based Learning was effective to use that was in the assessment interval of 64,7-95. Therefore, it can be said that the effectiveness of the PBL (Project Based Learning) learning model in distance learning on students' understanding of the material is categorized as effective.

\section{PENDAHULUAN}

Pendidikan saat ini sangat berperan penting dalam kemajuan suatu bangsa karena pendidikan penduduk mempengaruhi sumber daya manusia. Pendidikan yang berkualitas akan berpengaruh pada sekolah berkualitas juga dimana sekolah tersebut akan menghasilkan siswa-siswi yang berkualitas pula. Pendidikan adalah mempersiapkan manusia untuk memecahkan problem kehi-dupan pada masa kini maupun masa yang akan datang (Djumali, et al.). Menurut (Kurniawan, 2017) pendidikan adalah mengalihkan nilai-nilai, pengalaman, pengetahuan, serta kete-rampilan kepada generasi muda sebagai usaha generasi tua dalam menyiapkan fungsi hidup generasi selanjutnya baik dalam jasmani maupun rohani. Sedangkan secara yuridis, Pada UU Sistem Pendidikan Nasional Nomor 20 Tahun 2013 Pendidikan adalah mewujud-kan suasana belajar dengan usaha yang sadar dan terencana serta aktif mengembangkan potensi siswa, masyarakat, bangsa, dan negara melalui proses belajar mengajar.

Pada dasarnya, pendidikan merupakan usaha untuk mendewasakan seseorang dengan 
interaksi antara pendidik dan peserta agar tujuan pendidikan dapat tercapai melalui suatu proses. Proses yang digunakan dapat berupa pengajaran maupun pelatihan secara mendidik. Untuk menjalankan proses tersebut, salah satunya dapat menggunakan suatu model pembelajaran.

Model pembelajaran adalah suatu rangka konseptual yang menggambarkan prosedur secara sistematis dalam mengorganisasikan pengalaman belajar untuk mencapai tujuan belajar tertentu dan berfungsi sebagai pedoman bagai para perancang pembelajaran dan para pengajar dalam merencanakan dan melaksanakan aktivitas pembelajaran. Model pembelajaran ini nantinya akan dijadikan sebagai pedoman dalam proses pembelajaran (Saefuddin, 2014). Model pembelajaran merupakan pedoman yang menggunakan suatu pola dalam merencanakan pembelajaran di kelas (Suprijono, 2010). Salah satu contoh model pembelajaran yang dapat dijadikan sebagai pedoman dalam proses pembelajaran yaitu model pembelajaran Project Based Learning (PBL).

Project Based Learning adalah kegiatan pembelajaran melalui pendekatan pengajaran dan peserta didik diberikan tantangan melalui tugas yang nyata yang terkait dengan kehidupan sehari-harinya lalu dipecahkan secara bersama atau kelompok (Brandon Goodman, 2010). Menurut (Daryanto, 2012) Project Based Learning adalah model pembelajaran yang menggunakan suatu masalah untuk mengumpulkan serta mengintegrasikan pengetahuan baru berdasarkan pengalaman siswa dan beraktifitas secara nyata yang merupakan langkah awal. Project Based Learning merupakan model pembelajaran bersifat membangun, membina, dan memperbaiki berpotensi memberdayakan kemampuan kognisi tingkat tinggi. Project Based Learning berpusat pada siswa dan memberikan pengalaman belajar yang bermakna bagi siswa. Pengalaman belajar siswa/konsep dibangun berdasarkan produk yang telah dihasilkan dalam proses pembelajaran Project Based Learning (Afriana, 2015). Project Based Learning berpusat pada proses, fokus suatu permasalahan, berjangka waktu, unit pembelajaran yang mempunyai makna dengan menyatukan konsep-konsep dari komponen-komponen baik itu pengetahuan, disiplin ilmu, maupun lapangan (Ngalimun, 2013).

Project Based Learning ada agar siswa mampu bekerja sama/berkolaborasi dengan teman sebayanya dalam menyelesaikan proyek sehingga rasa empati serta tanggung jawab muncul pada diri siswa tersebut. Dengan adanya Project Based Learning siswa diberikan kesempatan untuk mengelola pembelajaran dikelas dengan melibatkan pekerjaan proyek. Pekerjaan proyek berisi tugas-tugas kompleks berdasarkan pertanyaan dan permasalahan yang menantang dan menuntun siswa agar dapat memecahkan masalah, investigasi, membuat keputusan, dan memberi kesempatan siswa untuk bekerja secara mandiri (Lestari, 2015) sehingga siswa tersebut paham dengan materi apa yang sedang diajarkan melalui eksperimennya sendiri.

Alur implementasi pada model pembelajaran Project Based Learning secara sederhana dapat diungkakan sebagai berikut (1) menyusun pertanyaan dasar, (2) menyusun rencana proyek, (3) menyusun jadwal, (4) monitoring, (5) menguji hasil, dan (6) evaluasi (Usnima, 2020).

Menurut Kurniasih, keunggulan penerapan model Project Based Learning yaitu: “1) meningkatkan motivasi belajar siswa untuk mendorong kemampuan mereka agar dapat melakukan pekerjaan penting, dan menghargai mereka; 2) meningkatkan kemampuan dalam memecahkan masalah; 3) membuat siswa menjadi lebih aktif dan berhasil memecahkan problem-problem yang kompleks; 4) meningkatkan kolaborasi: 5) mendorong siswa untuk mengembangkan dan mempraktikkan keterampilan komunikasinya; 6) meningkatkan keterampilan siswa dalam mengelola sumber; 7) memberikan pengalaman kepada siswa pembelajaran dan praktik dalam mengorganisasi proyek dan membuat alokasi waktu dan sumber-sumber lain seperti 
perlengkapan untuk menyelesaikan tugas; 8) menyediakan pengalaman belajar yang melibatkan siswa secara kompleks dan dirancang berkembang sesuai dunia nyata; 9) melibatkan para siswa untuk belajar mengambil informasi dan menunjukkan pengetahuan yang dimiliki, kemudian diimplementasikan dengan dunia nyata; 10) membuat suasana belajar menjadi menyenangkan, sehingga peserta siswa maupun pendidik menikmati proses pembelajaran." (Nurfitriyanti, 2016)

Untuk menjalankan model pembelajaran Project Based Learning siswa harus lebih aktif karena pada model ini, pembelajaran berpusat pada siswa. Siswa dilatih untuk membuat hipotesis serta memecahkan masalah yang dihadapinya. Tetapi, saat ini bumi sedang dilanda pandemi Covid-19. Covid-19 sudah banyak menginfeksi masyarakat Indonesia. Karena pandemi Covid-19 itulah dunia pendidikan juga terkena dampak dari pandemi tersebut. Yang awalnya pendidikan dilaksanakan secara tatap muka, sekarang ini dilaksanakan secara PJJ (Pembelajaran jarak jauh) sesuai dengan Surat Edaran Nomor 4 Tahun 2020 yaitu seluruh kegiatan di institusi pendidikan harus jaga jarak. Seluruh materi disampaikan di rumah masing-masing. Dampak yang lain yaitu beban pelajaran yang banyak dan siswa yang mudah bosan karena tidak bisa berinteraksi dengan guru maupun teman sebayanya.

Model pembelajaran Project Based Learning membuat siswa lebih berkembang dari segi kognitif, afektif, dan psikomotorik. Karena dengan model ini, siswa berpikir dan belajar dengan caranya sendiri, dengan berpikir sendiri, maka siswa tersebut akan mengembangkan pikirannya dan lebih fokus. Bekerja serta berpikir dengan cara mereka sendiri akan memunculkan sifat tanggung jawab terhadap diri sendiri pada siswa tersebut.

Dari paparan uraian di atas, juga sesuai pilihan Menteri Pendidikan Nadiem Makarim pada Surat Edaran Nomor 4 Tahun 2020 bahwa Project Based Learning ini dipilih sebagai model pembelajaran yang digunakan saat proses pembelajaran jarak jauh karena dengan menggunakan model pembelajaran Project Based Learning siswa mampu untuk berpikir mandiri, berkolaborasi/bekerja sama dengan teman sebaya, dan bereksplorisasi. Oleh karena itu, tulisan dengan judul "Efektivitas Model Pembelajaran PBL (Project Based Learning) pada Pembelajaran Jarak Jauh terhadap Pemahaman Materi Siswa" dilakukan. Dengan tujuan yaitu penggunaan model pembelajaran Project Based Learning ini efektif digunakan agar siswa paham dengan suatu materi yang diajarkan.

\section{METODE}

Penelitian dilakukan dengan menggunakan metode kuantitatif. Metode penelitian kuantitatif yaitu untuk meneliti sampel/ populasi tertentu yang berlandaskan pada filsafat positivisme, teknik pengambilan sampelnya dilakukan secara random, instrumen penelitian digunakan untuk pengambilan data, untuk menguji hipotesis yang sudah ditetapkan analisis datanya bersifat statistik/ kuantitatif (Sugiyono, 2013). Penelitian kuantitatif merupakan metode penelitian yang data-datanya diproses menggunakan angka sebagai alat untuk menganalisis dan melakukan kajian penelitian. (Kasiram, 2008).

Teknik pengumpulan data dilakukan dengan angket kuesioner. Angket/kuesioner adalah pertanyaan-pertanyaan tertulis untuk mengumpulkan informasi yang dibutuhkan oleh peneliti yang diisi oleh para subjek yang diteliti. Angket kuesioner pada penelitian ini peneliti sebarkan secara luas melalui sosial media dengan syarat dan ketentuan berlaku yang berisi 19 pertanyaan dengan subjek penelitian siswa di berbagai daerah dengan diisi sebanyak 50 responden. Teknik yang digunakan untuk pemberian skor dalam kuesioner ini dengan menggunakan teknik skala Likert. Penggunaan skala Likert digunakan untuk mengukur sikap, pendapat, dan persepsi seseorang/sekelompok orang tentang fenomena sosial. (Sugiyono, 2013). 
Agar dapat diambil kesimpulan apakah efektif atau tidak efektif peneliti menggunakan skala Likert. Peneliti mengumpulkan data terlebih dahulu dengan sampel yang tepat dan jumlah responden yang sesuai, setelah itu peneliti akan menjumlahkan seluruh data yaitu dengan cara mengklasifikasi berdasarkan jawaban yang diperoleh. Jawaban setiap instrumen tersebut mempunyai gradasi dari sangat setuju hingga sangat tidak setuju yang setiap gradasi mempunyai skor yang berbeda.

Tabel 1: Skala Likert

$\begin{array}{cc}\text { Kategori } & \text { Skor } \\ \text { Sangat setuju } & 5 \\ \text { Setuju } & 4 \\ \text { Ragu-ragu } & 3 \\ \text { Tidak setuju } & 2 \\ \text { Sangat tidak setuju } & 1\end{array}$

Langkah selanjutnya yaitu pemberian bobot pada masing-masing jawaban per responden, yang terakhir yaitu menentukan skor maximum dan skor minimum agar dapat diketahui interval penilaian yang selanjutnya juga agar diketahui apakah nilai indeks yang didapatkan efektif atau tidak efektif.

\section{HASIL PENELITIAN}

Pada penelitian ini menggunakan angket kuesioner yang didalamnya terdapat 19 pertanyaan dengan 50 responden. Responden mengisi angket kuesioner untuk menunjukan tingkat persetujuan terhadap serangkaian pertanyaan terkait penggunaan model pem=belajaran Project Based Learning terhadap pemahaman materi siswa pada pembelajaran jarak jauh saat ini. Untuk mengetahui apakah Project Based Learning efektif digunakan agar siswa paham dengan suatu materi yang diajarkan, maka peneliti menggunakan skala Likert dimana skor maksimal bernilai 5 dan skor minimal bernilai 1 dan skor lainnya dapat dilihat pada tabel 1 .

Pada angket kuesioner, peneliti telah memberikan total skor pada jawaban tiap responden yang terdiri dari 19 pertanyaan yang diajukan oleh peneliti. Hasil skor tiap responen berbeda-beda yang dapat dilihat pada tabel 1.3. Dari 50 responden, terdapat skor terendah yaitu 60 dan skor tertinggi yaitu 95 .

Skor maksimum $=$ skor maksimal item $\times$ jumlah pertanyaan

$=5 \times 19$

$=95$

Skor minimum $=$ skor minimal item $\times$ jumlah pertanyaan

$=1 \times 19$

$=19$

Interval $=$ (Skor maksimum-skor minimum)/(jumlah item)

$=(95-19) / 5$

$=15,2$

Dari hasil data di atas, didapat hasil skor maksimum 95, skor minimum 19, dan interval 15,2 yang selanjutnya dapat digunakan untuk mencari interval penilaian sebagai berikut :

Tabel 2: Interval Penilaian

$\begin{array}{cc}\text { Sangat efektif } & 79,9-95 \\ \text { Efektif } & 64,7-79,8 \\ \text { Cukup efektif } & 49,5-64,6 \\ \text { Tidak efektif } & 34,3-49,4 \\ \text { Sangat tidak efektif } & 19-34,2\end{array}$

Dari 50 responden berada pada interval penilaian yang berbeda-beda sesuai dengan total skor jawaban. Terdapat 15 responden yang berada pada interval penilaian 79,9 - 95 (sangat efektif), 29 responden berada pada interval penilaian 64,7 - 79,8 (efektif), 6 responden berada pada interval 49,5-64,6 (cukup efektif), 0 responden pada interval penilaian 34,3-49,4 (tidak efektif), dan 0 responden pada interval penilaian 19-34,2 (sangat tidak efektif). Efektivitas penggunaan PBL (Project Based Learning) pada pembelajaran jarak jauh terhadap pemahaman materi siswa menunjukkan kategori Efektif karena sebanyak 44 responden dari 50 responden berada pada interval penilaian 64,795.

Proses pembelajaran dengan model pembelajaran Project Based Learning pada 
pembelajaran jarak jauh dapat digunakan pendidik agar siswa tetap paham dengan materi yang diajarkan. Banyak siswa yang mempunyai semangat belajar meskipun pembelajaran jarak jauh. Kegiatan yang muncul pada semua tahapan Project Based Learning menunjukkan adanya kepahaman atau ketertarikan siswa dalam suatu materi. Hal tersebut menunjukkan tumbuhnya minat siswa terhadap Project Based Learning. Kondisi proses pembelajaran pada pembelajaran jarak jauh juga mengalami peningkatan. Jika sebelumnya pendidik menggunakan metode ceramah saat proses pembelajaran, dengan adanya model pembelajaran Project Based Learning, siswa cenderung lebih aktif karena tugas proyek yang diberikan oleh guru menunjang mereka untuk berkolaborasi, bekerja sama, dan berdiskusi dengan teman sebayanya.

Hasil penelitian ini sejalan dengan hasil penelitian yang telah dilakukan oleh (Rauziani, Yusrizal, \& Cut, 2016) menunjukkan bahwa model Project Based Learning dapat memberikan respon dan tanggapan yang baik pada peserta didik. Peserta didik juga berpikir kritis dan aktif dalam proses pembelajaran.

Sedangkan pada hasil penelitian yang telah dilakukan oleh (Sucipto, 2017) menunjukkan bahwa dengan menerapkan model Project Based Learning, siswa lebih aktif dengan berani bertanya, mendengarkan guru dengan seksama, mencatat hal-hal yang penting, dan saling berdiskusi dengan teman atau antar kelompok dalam menyelesaikan tugasnya.

Hal tersebut menunjukkan bahwa tujuan pembelajaran akan tercapai jika pendidik dapat memilih suatu model pembelajaran yang tepat sebagai pedoman. Model pembelajaran yang tepat akan membuat siswa cenderung lebih paham dengan materi yang diajarkan, dengan adanya paham materi tersebut maka siswa akan lebih aktif dalam proses pembelajaran. Begitu juga dengan penelitian yang telah dilakukan oleh (Rauziani, Yusrizal, \& Cut, 2016) "Implementasi Model Project
Based Learning (PjBL) dalam Meningkatkan Hasil Belajar dan Berpikir Kritis Siswa pada Materi Fluida Statis di SMA Inshafuddin" dan (Sucipto , 2017) “Penerapan Model Project Based Learning untuk Meningkatkan Minat dan Hasil Belajar IPS". Hasil penelitianpenelitian tersebut menunjukkan bahwa dengan menggunakan model Project Based Learning siswa lebih paham dengan materi yang diajarkan dan membuat siswa tersebut lebih aktif saat proses pembelajaran.

Berdasarkan analisis di atas, membuktikan bahwa penggunaan model Project Based Learning pada pembelajaran jarak jauh efektif digunakan pendidik saat proses pembelajaran. Hal tersebut dapat dilihat bahwa 44 dari 50 responden yang merupakan siswa dari berbagai daerah berada pada kategori efektif.

\section{SIMPULAN}

Dapat disimpulkan bahwa Project Based Learning ini efektif digunakan agar siswa paham dengan suatu materi yang diajarkan karena Project Based Learning mempunyai sifat membangun, membina, serta meningkatkan potensi yang ada pada siswa. Dengan menggunakan model pembelajaran Project Based Learning siswa akan lebih fokus pada dirinya sendiri untuk berpikir mengenai ide apa yang akan ia kemukakan sehingga siswa akan lebih berkembang dan lebih mengenal dirinya sendiri sehingga materi yang disampaikan juga lebih mudah dipahami oleh siswa.

Project Based Learning juga mempunyai tujuan agar siswa lebih mandiri dan aktif dalam pembelajaran agar pengetahuan yang sudah dimiliki oleh siswa lebih mudah untuk diterapkan, dan agar keterampilan berpikir serta sikap siswa dapat terus dilatih.

Project Based Learning terbukti efektif digunakan agar siswa paham dengan suatu materi yang diajarkan pada pembelajaran jarak jauh. Terbukti pada hasil pembahasan diperoleh interval penilaian 64,7-95 pada interval penilaian tersebut terdapat 44 responden dari 50 responden yang berarti efektivitas 
penggunaan PBL (Project Based Learning) pada pembelajaran jarak jauh terhada pemahaman materi siswa menunjukkan kategori efektif.

\section{DAFTAR PUSTAKA}

Afriana, J. Project Based Learning Makalah untuk Tugas Mata Kuliah Pembelajaran IPA Terpadu. Bandung: Program Studi Pendidikan IPA Sekolah Pascasarjana Universitas Pendidikan Indonesia. 2015.

Brandon Goodman, J. S. Project-Based Learning . Educational Psychology. 2010.

Daryanto, M. Model Pembelajaran Inovatif. Yogyakarta: Gava Media. 2012.

Djumali, Sundari, Ali, S., Subadi, J., Choiri, A., \& Wardhani, J. (2014). Landasan Pendidikan. Yogyakarta: Gava Media. 2014.

Kasiram, M. (2008). Metode Penelitian Kuantitatif Kualitatif. Malang: UIN Malang Press. 2008.

Kurniawan, S. Pendidikan Karakter Konsepsi dan Implementasi secara Terpadu di Lingkungan Keluarga, Sekolah, Perguruan Tinggi dan Masyarakat. Yogyakarta: Ar-Ruzz Media. 2017.

Lestari, T. Peningkatan Hasil Belajar Kompetensi Dasar Menyajikan Contoh-contoh Ilustrasi Dengan Model Pembelajaran Project Based Learning dan Metode Pembelajaran Demonstrasi Bagi Siswa Kelas XI Multimedia SMK Muhammadiyah Wonosari. Yogyakarta: Program Studi Pendidikan Teknik Informatika Fakultas Teknik Universitas Negeri Yogyakarta. 2015.

Ngalimun. Strategi dan Model Pembelajaran. Yogyakarta: Aswaja Pressindo.2013.

Nurfitriyanti, M. Model Pembelajaran Project Based Learning terhadap Kemampuan Pemecahan Masalah Matematika. Jurnal Informatif. 2016.

Rauziani, Yusrizal, \& Cut, N. Implementasi Model Project Based Learning (PjBL) dalam Meningkatkan Hasil Belajar dan Berpikir Kritis Siswa pada Materi Fluida. Jurnal Pendidikan Sains Indonesia. 2016.

Saefuddin, B. Pembelajaran Efektif. Bandung: PT. Remaja Rosdakarya. 2014

Sucipto , H. Penerapan Model Project Based Learning untuk Meningkatkan Minat dan Hasil Belajar IPS. Jurnal Pendidikan: Riset \& Konseptual. 2017.

Sugiyono. Metode Penelitian Pendidikan Pendekatan Kuantitatif, Kualitatif, dan R\&D. Bandung: Alfabeta. 2013.

Suprijono, A. Cooperative Learning. Yogyakarta: Pustaka Media. 2010.

Usnima. Gurusiana. Diambil kembali dari Gurusiana.id: https://usnima.gurusiana.id/article/2020/09/webinar-implementasi-pbl-pada-saat-pjjtantangan-menulis-gurusiana-hari-ke-191-1731873. 2020 